\title{
Energy and Environmental Research Emphasizing Low-Rank Coal -- Task 6.1 Corrosion of Advanced Structural Materials
}

\section{Topical Report}

Jan W. Nowok Tina M. Strobel Jay A. Bieber

John P. Hurley

April 1995

Work Performed Under Contract No.: DE-FC21-93MC30097

For

U.S. Department of Energy

Office of Fossil Energy

Morgantown Energy Technology Center

Morgantown, West Virginia

By

University of North Dakota

Grand Forks, North Dakota

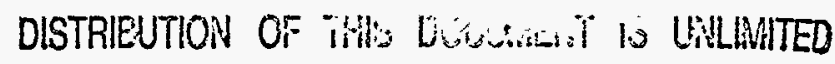




\title{
Energy and Environmental Research Emphasizing Low-Rank Coal -- Task 6.1 Corrosion of Advanced Structural Materials
}

\section{Topical Report}

\author{
Jan W. Nowok \\ Tina M. Strobel \\ Jay A. Bieber \\ John P. Hurley
}

Work Performed Under Contract No.: DE-FC21-93MC30097

\author{
For \\ U.S. Department of Energy \\ Office of Fossil Energy \\ Morgantown Energy Technology Center \\ P.O. Box 880 \\ Morgantown, West Virginia 26507-0880 \\ By \\ University of North Dakota \\ Energy and Environmental Research Center \\ P.O. Box 9018 \\ Grand Forks, North Dakota 58202-9018
}




\section{ACKNOWLEDGMENT}

This topical report was prepared with the support of the U.S. Department of Energy (DOE) Morgantown Energy Technology Center Cooperative Agreement No. DE-FC21-93MC30097. However, any opinions, findings, conclusions, or recommendations expressed herein are those of the author(s) and do not necessarily reflect the views of the DOE. 
LIST OF FIGURES $\ldots \ldots \ldots \ldots \ldots \ldots \ldots \ldots \ldots \ldots \ldots \ldots \ldots \ldots \ldots \ldots \ldots \ldots$

LIST OF TABLES $\ldots \ldots \ldots \ldots \ldots \ldots \ldots \ldots \ldots \ldots \ldots \ldots \ldots \ldots \ldots \ldots \ldots$ iii

1.0 INTRODUCTION $\ldots \ldots \ldots \ldots \ldots \ldots \ldots \ldots \ldots \ldots \ldots \ldots \ldots \ldots \ldots \ldots \ldots$

2.0 THERMODYNAMIC MODELING $\ldots \ldots \ldots \ldots \ldots \ldots \ldots \ldots \ldots \ldots$

3.0 COAL SLAG CORROSION $\ldots \ldots \ldots \ldots \ldots \ldots \ldots \ldots \ldots \ldots \ldots \ldots \ldots \ldots \ldots \ldots$

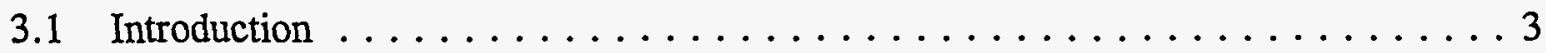

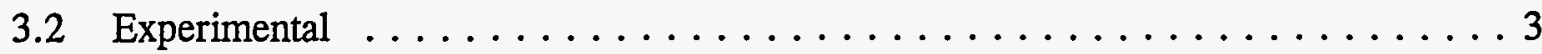

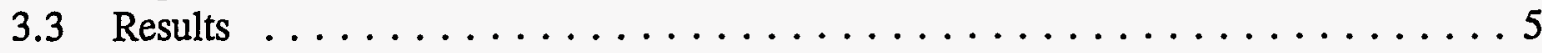

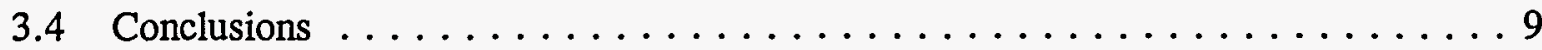

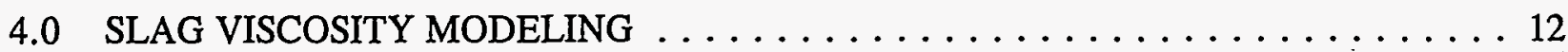

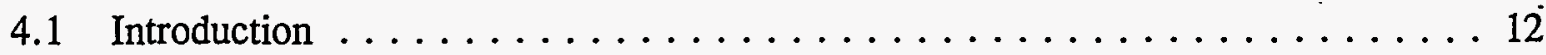

4.2 Viscosity and Its Practical Application $\ldots \ldots \ldots \ldots \ldots \ldots \ldots \ldots \ldots \ldots$

4.3 On the Crystallinity, Probability of Occurrence, and Rheology of Ash Slags . . . . 13

5.0 PARTICULATE COAL ASH CORROSION $\ldots \ldots \ldots \ldots \ldots \ldots \ldots \ldots \ldots$

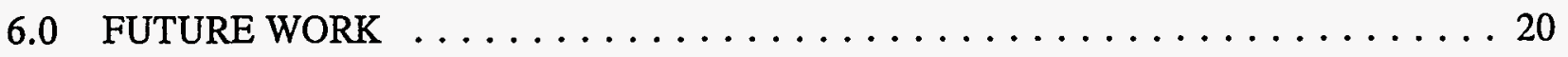

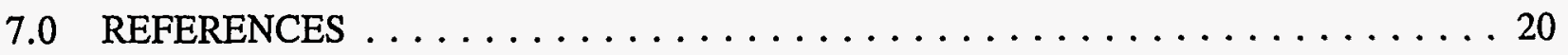




\section{LIST OF FIGURES}

1 SEM photo showing the cross section through the Coors $\beta-S i C$ exposed to

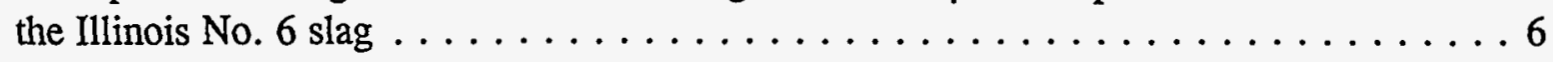

2 SEM photo showing a decrease in thickness of the $\mathrm{MoSi}_{2}$ and reaction at

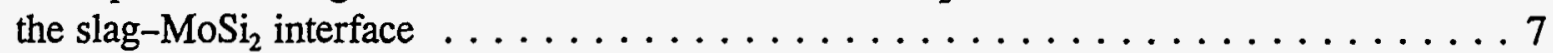

3 SEM photo showing bright areas rich in molybdenum and iron above the slag- $\mathrm{MoSi}_{2}$ interface $\ldots \ldots \ldots \ldots \ldots \ldots \ldots \ldots$

$4 \quad \mathrm{SEM}$ photo showing a cross section through the $\mathrm{MoSi}_{2}$ exposed to the Illinois No. 6 slag showing little corrosion of the $\mathrm{MoSi}_{2}$ surface $\ldots \ldots \ldots \ldots \ldots$

5 Viscosity vs. temperature in air $+10 \mathrm{wt} \% \mathrm{H}_{2} \mathrm{O}$ for the Illinois No. 6

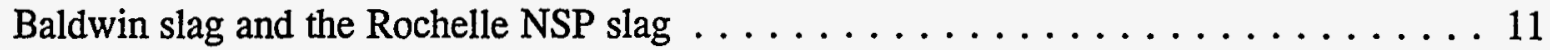

6 Viscosity of Rochelle ash slag measured in air $\ldots \ldots \ldots \ldots \ldots \ldots$

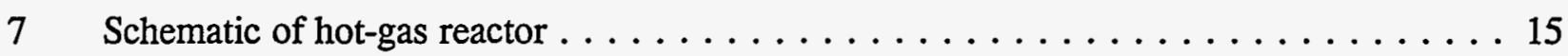

8 Photograph of completed hot-gas reactor $\ldots \ldots \ldots \ldots \ldots \ldots$

9 Filter assembly with mounted filter section $\ldots \ldots \ldots \ldots \ldots$

10 Filter sections before and after 500 -hour test $\ldots \ldots \ldots \ldots \ldots$

11 SEM micrographs of a cross section of the ash cake and filter interface a) before a 500 -hour exposure and b) after the 500 -hour exposure . . . . . . . . . 19 


\section{LIST OF TABLES}

1 Ceramic Materials Used in the Corrosion Experiments . . . . . . . . . . . . 4

2 Compositions of the Rochelle and Illinois No. 6 Slags Used in the Corrosion Tests . . . . 4

3 Remaining Strengths and Penetration Depths for the Test Samples

Exposed at $1260^{\circ} \mathrm{C}$ to Rochelle Slags . . . . . . . . . . . . . . . 9

4 Remaining Strengths and Penetration Depths for the Test Samples

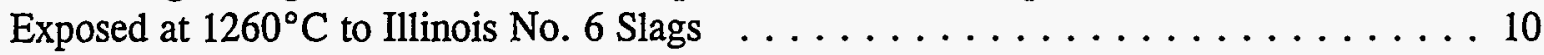

5 Compositions of the Rochelle and Illinois No. 6 Ashes

Used in the Combustion 2000 Corrosion Tests . . . . . . . . . . . . . . . 10 


\section{TASK 6.1 CORROSION OF ADVANCED STRUCTURAL MATERIALS}

\subsection{INTRODUCTION}

In order to increase national energy self-sufficiency for the near future, energy systems will be required to fire low-grade fuels and use more efficient energy cycles than those available today. The steam cycle used at present is limited to a maximum steam temperature of $550^{\circ} \mathrm{C}$ and thus a conversion efficiency of $35 \%$. To boost efficiency significantly, much higher working fluid temperatures are required, compelling subsystems to operate at much higher temperatures and, therefore, in much more corrosive environments than those currently used. Problems of special concern are corrosion and fatigue of direct-fired turbine blades, corrosion and blinding of hot-gas cleanup filters, catastrophic failure of high-temperature heat exchangers, and spalling and dissolution of refractory materials. The extreme conditions will require the use of advanced structural materials such as high-temperature ceramics for the construction of the subsystems. Unfortunately, little is known of the performance of these materials in actual coal combustion environments. Although some corrosion testing has been performed in the past, most has been done by groups experimenting with ash or slag simulants composed of only one or two simple compounds. For this project performed at the Energy \& Environmental Research Center (EERC), actual coal ash and slag will be used in simulated combustion conditions so that more realistic determinations of the mechanisms of corrosion can be made.

The work includes three main research areas focusing on two fossil energy subsystems: high-temperature heat exchangers and hot-gas cleanup filters. The first area involves developing existing abilities in thermodynamic equilibrium calculations to determine the most appropriate corroding agents to include in the tests; the second area involves coal slag corrosion of hightemperature heat exchangers; and the third, lower-temperature ash and gas corrosion hot-gas cleanup filters.

\subsection{THERMODYNAMIC MODELING}

To appropriately design corrosion tests to simulate the conditions in a fossil energy subsystem, the correct types and quantities of corrosion agents must be used. The easiest way to determine these is to perform computer modeling of the state of the products of coal utilization as they would exist in the energy system at the location of the subsystem of interest. Therefore, this research area was originally designed to extend our existing modeling capabilities with a computer program written at the EERC called Thermochemical Equilibrium Analysis of Coal and AsH, or TEACH. However, the researcher that developed TEACH left suddenly, and the program is in a form not usable by other researchers. This is also the reason that the static lattice energy calculations (SLEC) work was canceled from the milestones.

Because of the loss of the TEACH code, existing thermochemical equilibrium codes created at other organizations were tested to find the most appropriate one for our needs. Most thermodynamic models developed for silicate melts and glasses of geologically significant compositions operate on a principle of the chemical equilibrium: minimization of the Gibbs free energy as a function of temperature $(\mathrm{T})$, pressure $(\mathrm{P})$, and composition $(\mathrm{X})$. For any system of fixed composition, the general equilibrium condition can be expressed by the following: 


$$
\operatorname{minimize} G=\sum_{k=1}^{N} n_{k} \cdot G_{k}
$$

where $n_{k}$ is the number of moles, and $G_{k}$ represents the molar Gibbs free energy of the phase $k$ (1).

Speciation and stoichiometric models have been proposed to describe the free energy of silicate melts (2). The speciation approach gives a complex solution phase in which the number of chemical species mixing in the solution is greater than the number of thermodynamic components. The stoichiometric approach leads to a simple solution in which the number of chemical entities is equal to the number of components. The most important point in recognition of an appropriate model is to determine the existence of a "feasible region" that is consistent with all inequalities representing the $P, T, X$ positions and to further minimize an objective function in order to optimize some linear combination of variables.

Generally, structural units (clusters) in an aluminosilicate melt have a tendency to order with decreasing temperature. This behavior is observed in the temperature dependence of the thermodynamic mixing properties (such as the melt Gibbs free energy $\Delta G_{\text {mix }}$, enthalpy $\Delta H_{\text {mix }}$, and entropy $\Delta S_{\text {mix }}$ ) all decrease with decreasing temperature (3), and are affected by the minor constituents in the melt (4). For a pure system at equilibrium, only one assemblage can occur for which the chemical potential $(\mu)$ of a component in solution is equivalent to that of the corresponding crystalline phase. Thus, we may say the following (5):

$$
\mu_{i}^{(s o l)}=\mu_{i}^{(s)}
$$

If we add new phases to the system, as a result of multistep precipitation from the multicomponent solution, the mathematical treatment becomes more complex. The important part of the algorithm is the search for phase and/or phases with the minimum Gibbs free energy. Difficulties may arise if the primary crystallized phases with the lowest Gibbs free energy will interact with secondary solidified phases at lower temperatures and form a new system. As an example, a melt containing $\mathrm{Na}_{2} \mathrm{O}-\mathrm{MgO}-\mathrm{CaO}-\mathrm{Al}_{2} \mathrm{O}_{3}-\mathrm{SiO}_{2}$ may crystallize upon cooling with the precipitation of diopside $\left(\mathrm{CaO} \cdot \mathrm{MgO} \cdot 2 \mathrm{SiO}_{2}\right)$ and then nepheline $\left(\mathrm{Na}_{2} \mathrm{O} \cdot \mathrm{Al}_{2} \mathrm{O}_{3} \cdot 2 \mathrm{SiO}_{2}\right)$; both phases may further react and form new phases (6). The phase diagram features (new eutectics, new solid solutions and phases) are related to a stability hierarchy among the predicted phases. As a consequence, a new equilibrium between nepheline and diopside will occur. The following reaction illustrates the possible disappearance of diopside and nepheline in crystallized solution.

$$
3 \mathrm{CaMgSi}_{2} \mathrm{O}_{6}+2 \mathrm{NaAlSiO}_{4}=\left(\mathrm{Ca}_{2} \mathrm{MgSi}_{2} \mathrm{O}_{7}+\mathrm{CaNaAlSi}_{2} \mathrm{O}_{7}\right)_{\text {solution }}+\mathrm{Mg}_{2} \mathrm{SiO}_{4}+\mathrm{NaAlSi}_{3} \mathrm{O}_{8}
$$

The disadvantage of using phase diagram data alone is that the diagram provides information on the temperature as a function on composition and not on the variation of Gibbs free energy with composition, and the enthalpy and entropy contributions to the Gibbs free energy of mixing cannot be obtained. Our present knowledge of mutual interaction of crystalline phases in the remaining liquid phase is limited. 
Two widely available thermochemical equilibrium computer programs are currently being evaluated: SOLGAS 501 and NASA codes. Neither program is currently designed to predict the crystallization behavior of multicomponent silicate mixtures. SOLGAS 501 can be used to calculate the total heat of reaction for gas systems. The NASA program allows the calculation of enthalpy, entropy, heat capacity, and composition of constituents after reaction as a function of temperature; however, some uncertainties exist as to the accuracy, and the program ignores constraints of Gibbs free energy as a primary thermodynamic function.

\subsection{COAL SLAG CORROSION}

\subsection{Introduction}

Since this work was proposed, similar slag corrosion tests of several silicon-based ceramic monolithic and composite materials have been performed at the EERC under the Combustion 2000 project. Therefore, the conditions of the tests to be performed under this task were changed to match those of the Combustion 2000 tests so that better comparisons of results could be made. Also, it became obvious from the Combustion 2000 work that the composition of the slag can strongly influence the corrosion rates and mechanisms. It was decided to halve the number of materials, but use two types of slags to corrode each of the materials rather than one slag as originally proposed. However, it was not possible to obtain test specimens for each of the materials that had the correct shape for strength testing, so the flexure tests were omitted from the test matrix, and the funds were shifted to improving the test reactor used in the dry ash corrosion tests which are also part of this task.

\subsection{Experimental}

Because of the delays in the receipt of funds for this project and the difficulty in obtaining test materials, the corrosion tests had not been performed by the end of the calendar year 1994 . Instead, they were performed in the first quarter of 1995. Two silicon-based ceramics and one intermetallic were examined in 300 -hour slag corrosion tests at $1260^{\circ} \mathrm{C}$, the same conditions as used in the Combustion 2000 tests. The materials were Coors' Direct Sintered $\beta$-SiC (DSSC), Norton NT154 silicon nitride $\left(\mathrm{Si}_{3} \mathrm{~N}_{4}\right)$, and molybdenum disilicide $\left(\mathrm{MoSi}_{2}\right)$ from a Kanthal heating element. Several 20 -mm-diameter disks of the $\beta$-SiC were donated by Coors for the corrosion tests. Characteristics of the materials are listed in Table 1. The $\beta$-SiC from Coors is composed of $92 \% \alpha$-SiC (hexagonal) and $8 \% \beta$-SiC (cubic). The material is processed by firing a powder of $\beta$ $\mathrm{SiC}$ to $2000^{\circ} \mathrm{C}$, during which a phase change from $\beta$ - to $\alpha$-SiC occurs at $1600^{\circ}-1700^{\circ} \mathrm{C}$. General Electric owns the patent for processing $\mathrm{SiC}$ in this manner, whereas the Carborundum Co. owns the patent for firing $\alpha-\mathrm{SiC}$ powder to produce Hexoloy SA silicon carbide.

The NT154 silicon nitride is composed of $96 \% \mathrm{Si}_{3} \mathrm{~N}_{4}$ and $4 \% \mathrm{Y}_{2} \mathrm{O}_{3}$. Yttria $\left(\mathrm{Y}_{2} \mathrm{O}_{3}\right)$ is added to the Norton NT154 Si $\mathrm{N}_{4}$ to decrease the sintering temperature of the material. Although the flexural and compressive strengths of the NT154 are greater than those of the $\beta$-SiC, the thermal conductivity of the $\beta-\mathrm{SiC}$ is greater. Compared with the Si-based ceramics, the $\mathrm{MoSi}_{2}$ has a lower flexure strength and lower thermal conductivity.

The compositions of the two slags used in the corrosion experiments are given in Table 2. Both slags were collected from cyclone-fired utility boilers and are being used by other researchers 
TABLE 1

Ceramic Materials Used in the Corrosion Experiments

\begin{tabular}{|c|c|c|c|}
\hline Type & $\begin{array}{l}\text { Coors } \\
\beta \text {-SiC } \\
\end{array}$ & $\begin{array}{c}\text { Norton NT154 } \\
\beta-\mathrm{Si}_{3} \mathrm{~N}_{4} \\
\end{array}$ & $\mathrm{MoSi}_{2}$ \\
\hline Composition, wt\% & & & \\
\hline $\mathrm{SiC}$ & 99 & & \\
\hline $\mathrm{Si}_{3} \mathrm{~N}_{4}$ & & 96 & \\
\hline $\mathrm{Y}_{2} \mathrm{O}_{3}$ & & 4 & \\
\hline $\mathrm{MoSi}_{2}$ & & & 99 \\
\hline Density, $\mathrm{g} / \mathrm{cm}^{3}$ & 3.1 & 3.2 & 5.6 \\
\hline $\begin{array}{l}\text { Flexural Strength, MPa } \\
\text { 4-point @ } 25^{\circ} \mathrm{C}\end{array}$ & 371 & 490 & 450 \\
\hline $\begin{array}{l}\text { Compressive Strength, Mpa } \\
\text { @ } 25^{\circ} \mathrm{C}\end{array}$ & 2110 & 3000 & 1450 \\
\hline $\begin{array}{l}\text { Thermal Conductivity, W/m K } \\
@ 25^{\circ} \mathrm{C} \\
@ 1000^{\circ} \mathrm{C}\end{array}$ & 125 & 38 & $\begin{array}{l}30 \\
15\end{array}$ \\
\hline $\begin{array}{l}\text { Coefficient of Thermal Expansion } \\
\left(\mathrm{x} 10^{-6} /{ }^{\circ} \mathrm{C}\right)\end{array}$ & 4.4 & 3.3 & 7.5 \\
\hline
\end{tabular}

TABLE 2

Compositions of the Rochelle and Illinois No. 6 Slags Used in the Corrosion Tests (normalized weight percents)

\begin{tabular}{lcc}
\hline Sample & $\begin{array}{c}\text { Rochelle } \\
\text { NSP Slag }+3 \% \text { Pet Coke } \\
(950052)\end{array}$ & $\begin{array}{c}\text { Illinois No. } 6 \\
\text { Baldwin Plant } \\
(950151)\end{array}$ \\
\hline Oxide, wt\% & & \\
$\mathrm{SiO}_{2}$ & 47.1 & 53.3 \\
$\mathrm{Al}_{2} \mathrm{O}_{3}$ & 18.8 & 18.6 \\
$\mathrm{Fe}_{2} \mathrm{O}_{3}$ & 5.2 & 17.6 \\
$\mathrm{TiO}_{2}$ & 1.4 & 0.7 \\
$\mathrm{PO}_{2}$ & 0.6 & 0.0 \\
$\mathrm{CaO}$ & 19.6 & 7.2 \\
$\mathrm{MgO}$ & 5.8 & 1.0 \\
$\mathrm{Na}_{2} \mathrm{O}$ & 0.9 & 0.0 \\
$\mathrm{~K}_{2} \mathrm{O}$ & 0.3 & 1.7 \\
$\mathrm{SO}_{3}$ & 0.3 & 0.0 \\
& & \\
$\mathrm{Closure}$ & 100.6 & 99.4 \\
\hline
\end{tabular}


involved in Combustion 2000 corrosion studies. The Rochelle slag was from the Northern States Power (NSP) Riverside plant. In addition to the coal, approximately $3 \%$ of the fuel input was petroleum coke, which is very low in ash but contains some vanadium $(<0.1 \mathrm{wt} \%$ in the slag). The Illinois No. 6 slag was from the Illinois Power Company Baldwin plant.

Two tiles of NT154, measuring approximately $70 \mathrm{~mm} \times 50 \mathrm{~mm} \times 7 \mathrm{~mm}$, and two disks of Coors' $\beta$-SiC, approximately $6 \mathrm{~mm}$ thick, were embedded in castable refractory boats. The exposed surfaces of all materials were cleaned with hydrofluoric acid prior to the tests. The $\beta$-SiC and $\mathrm{Si}_{3} \mathrm{~N}_{4}$ were coated with enough of each type of pulverized slag to produce a 5 -mm thick slag layer at the appropriate temperature. Cylindrical rods of the $\mathrm{MoSi}_{2}, 6 \mathrm{~mm}$ in diameter by $10 \mathrm{~cm}$ long, were placed upright in a SiC castable refractory crucible, 1" diameter and 4" high. Pulverized slag was placed in the base of the crucible to produce a $2.5-\mathrm{cm}$ layer of slag in the base. The six samples, three materials with two slag types, were placed in an atmospheric muffle furnace. The furnace temperature was raised at a rate of $120^{\circ} \mathrm{C} / \mathrm{hour}$, and the samples were exposed for 300 hours at $1260^{\circ} \mathrm{C}$. Then, the samples were cooled at a rate of $120^{\circ} \mathrm{C} /$ hour to ambient temperature. The samples were cross-sectioned and examined by scanning electron microscopy (SEM) to determine corrosion mechanisms and rates.

\subsection{Results}

\section{Coors $\beta-$ SiC/Rochelle Slag}

The $\beta$-SiC was coated with a 3-4-mm layer of mottled tan slag. The slag contained some large vesicles, indicating some reaction causing the release of gases. The surface of the ceramic was slightly pitted to a maximum depth of $150 \mu \mathrm{m}$. Iron silicide and iron phosphide corrosion products were present at the ceramic surface and in the slag and ranged in composition from $\mathrm{Fe}_{3}(\mathrm{Si}, \mathrm{P})$ to $\mathrm{Fe}_{4}(\mathrm{Si}, \mathrm{P})$. The slag showed an increase in silicon content and decreased in magnesium and iron contents after the 300-hour exposure. The increase in silicon is probably related to the dissolution of the $\mathrm{SiC}$ into the slag, whereas the decrease in $\mathrm{Fe}$ is a result of the formation of iron silicides.

\section{Coors $\beta$-SiC/Illinois No. 6 Slag}

A 1-3-mm layer of purplish/black slag was present on the surface of the $\beta$-SiC during the exposure. A canopy or bubble of slag 2-3 mm thick covered the opening of the refractory boat, essentially sealing the underlying slag and ceramic from the atmosphere. Small pits, $<75 \mu \mathrm{m}$ deep, were present at the slag-ceramic interface and were lined with small iron silicides. Larger iron silicides and vesicles were present in the overlying slag (Figure 1). The residual slag showed a 15 -wt\% increase in silicon and a 10 -wt\% decrease in iron relative to the pre-exposure composition. The increase in silicon can be explained by the dissolution of $\mathrm{SiC}$ into the slag, and the decrease in iron is explained by the formation of iron silicides $\left(\mathrm{Fe}_{2} \mathrm{Si}\right.$ and $\left.\mathrm{Fe}_{4} \mathrm{Si}_{3}\right)$ at the slag-ceramic interface.

\section{NT154 $\mathrm{Si}_{3} \mathrm{~N}_{1} /$ Rochelle Slag}

The $\mathrm{Si}_{3} \mathrm{~N}_{4}$ surface was covered with an 8-10-mm layer of highly vesicular tan slag. During machining of the sample, most of the slag became detached from the ceramic. The recession of the 


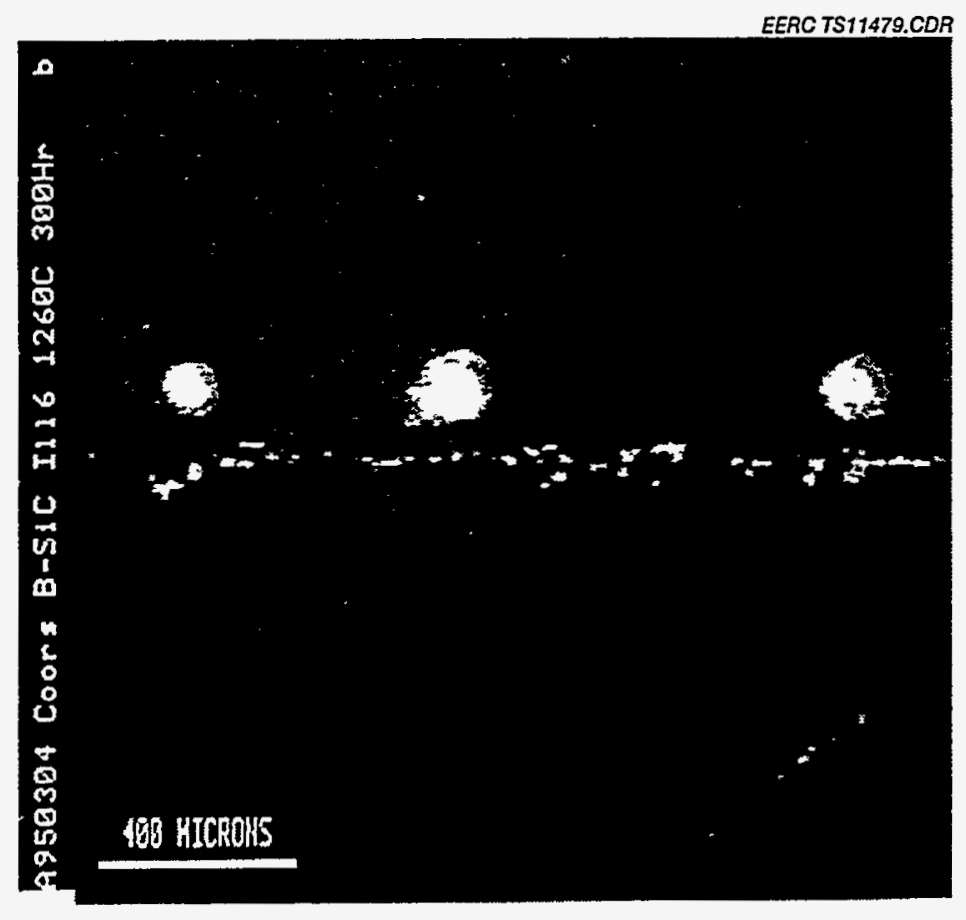

Figure 1. SEM photo showing the cross section through the Coors $\beta$-SiC exposed to the Illinois No. 6 slag. Circular iron silicides are present along the slag-ceramic interface.

ceramic surface reached a maximum depth of $480 \mu \mathrm{m}$. The residual slag contained $15 \mathrm{wt} \%$ more silicon and less $\mathrm{Mg}, \mathrm{Ca}$, and $\mathrm{Fe}$ than the slag before the exposure. The increase in silicon is attributed to the extensive dissolution of the $\mathrm{Si}_{3} \mathrm{~N}_{4}$ by the Rochelle slag. No corrosion products were identified in this sample, although other similar studies have shown yttrium silicates and cristobalite as some corrosion/oxidation products of $\mathrm{Si}_{3} \mathrm{~N}_{4}(8,9)$. Similar to the protective silica layer that can form on $\mathrm{SiC}$ exposed to oxidizing conditions, $\mathrm{Si}_{3} \mathrm{~N}_{4}$ can also develop a layer of $\mathrm{SiO}_{2}$. In some cases, a layer of $\mathrm{Si}_{2} \mathrm{~N}_{2} \mathrm{O}$ can form between $\mathrm{Si}_{3} \mathrm{~N}_{4}$ and $\mathrm{SiO}_{2}$ during oxidation (10). However, neither of these oxidation products were present on the Norton NT154 $\mathrm{Si}_{3} \mathrm{~N}_{4}$ after the 300-hour exposure.

\section{NT154 $\mathrm{Si}_{3} \mathrm{~N}_{1} / \mathrm{Illinois} \mathrm{No.} 6 \mathrm{Slag}$}

The $\mathrm{Si}_{3} \mathrm{~N}_{4}$ was coated with a glassy, black slag layer 5-9 mm thick. The top surface of the slag was metallic, possibly indicating the presence of Fe-rich crystalline phases at the surface. Surface recession of the ceramic was even, and ranged from 120 to $160 \mu \mathrm{m}$. The slag completely detached from the ceramic during machining. The residual slag contained $10 \mathrm{wt} \%$ more silicon and $10 \mathrm{wt} \%$ less iron than the original slag, indicating dissolution of the $\mathrm{Si}_{3} \mathrm{~N}_{4}$ into the slag and formation of iron silicides. The composition of the iron silicides indicated the presence of the phases $\mathrm{Fe}_{2} \mathrm{Si}$ and $\mathrm{Fe}_{3} \mathrm{Si}$.

\section{$\underline{\mathrm{MoSi}}_{2} / \mathrm{Rochelle} \mathrm{Slag}$}

A 2.5-mm layer of slag remained in the base of the $\mathrm{SiC}$ crucible. The $\mathrm{MoSi}_{2}$ rod was crosssectioned near the atmosphere-slag interface. The diameter of the $\mathrm{MoSi}_{2}$ rod showed a decrease in 
thickness of $580 \mu \mathrm{m}$ because of corrosion by the slag (Figure 2). A back scatter electron image of the slag- $-\mathrm{MoSi}_{2}$ interface shows a cloud-like front of Mo migrating into the slag (Figure 3). The maximum dissolution of $\mathrm{MoSi}_{2}$ into the slag seems to have occurred at the lowest possible partial pressure of oxygen in the slag, at the greatest distance from the atmosphere-slag interface. Other studies indicate that silicate liquids can only accommodate approximately $3-5 \mathrm{wt} \% \mathrm{Mo}$ (11). Therefore, some of the corroded $\mathrm{MoSi}_{2}$ remains as a separate phase in the slag, as the slag has reached its Mo saturation point. Other phases present in the slag include one rich in $\mathrm{Fe}$, $\mathrm{Mo}$, and $\mathrm{Si}$, which may be an alloy resulting from the interaction of $\mathrm{Fe}$ in the slag with the $\mathrm{MoSi}_{2}$ rod.

\section{$\mathrm{MoSi}_{2} /$ Illinois No. 6 Slag}

During the 300-hour exposure, the Illinois No. 6 slag foamed over the top of the crucible containing the $\mathrm{MoSi}_{2}$ rod. Therefore, an uneven coating of slag was present all along the $\mathrm{MoSi}_{2}$ rod. The sample was sectioned near the base of the crucible to obtain the thickest slag coating on the rod to examine with SEM. Postexposure measurements indicated a reduction in thickness of the rod of $<50 \mu \mathrm{m}$, indicating little corrosion by the slag (Figure 4). The remaining slag composition was heterogeneous because of some dissolution of the $\mathrm{MoSi}_{2}$ and some crystallization

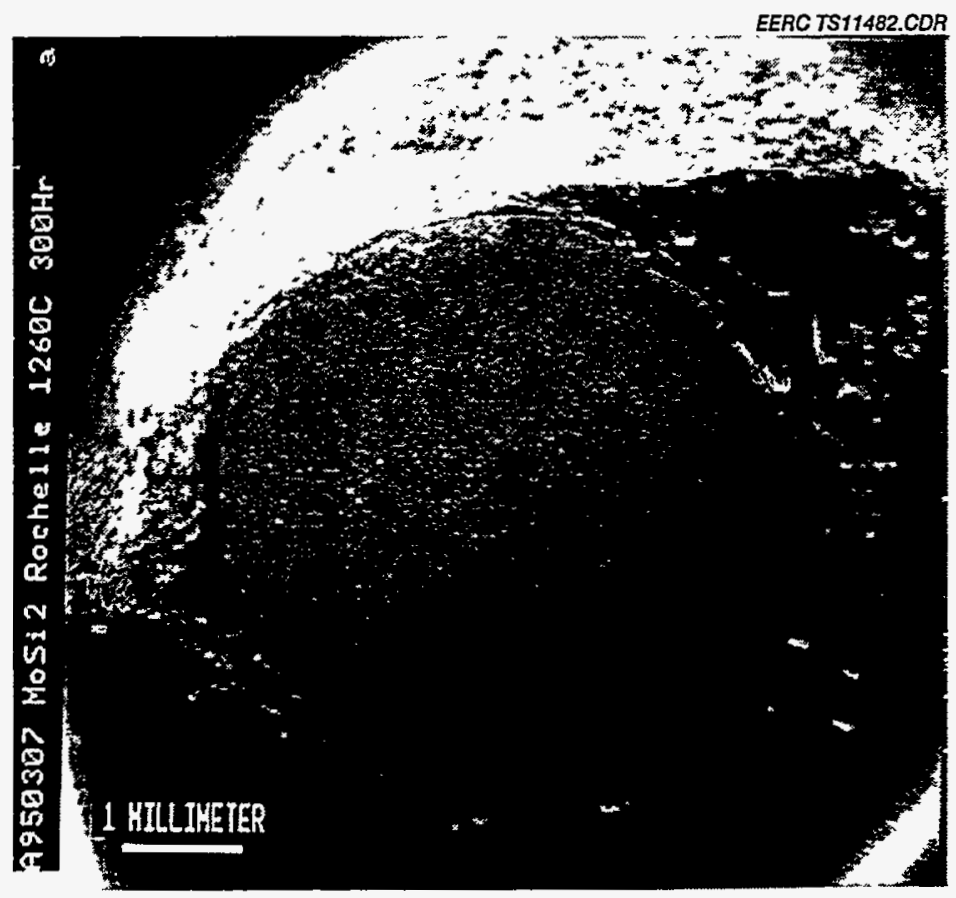

Figure 2. SEM photo showing a decrease in thickness of the $\mathrm{MoSi}_{2}$ and reaction at the slag- $\mathrm{MoSi}_{2}$ interface. 


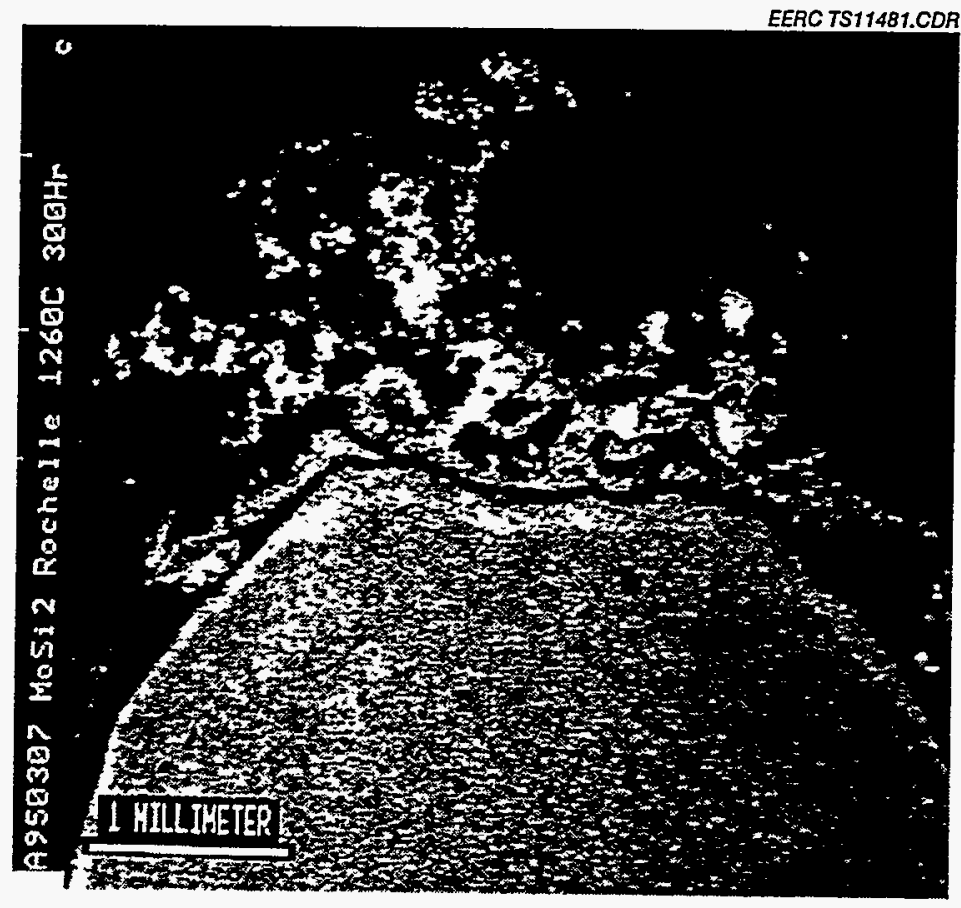

Figure 3. SEM photo showing bright areas rich in molybdenum and iron above the slag-MoSi interface.

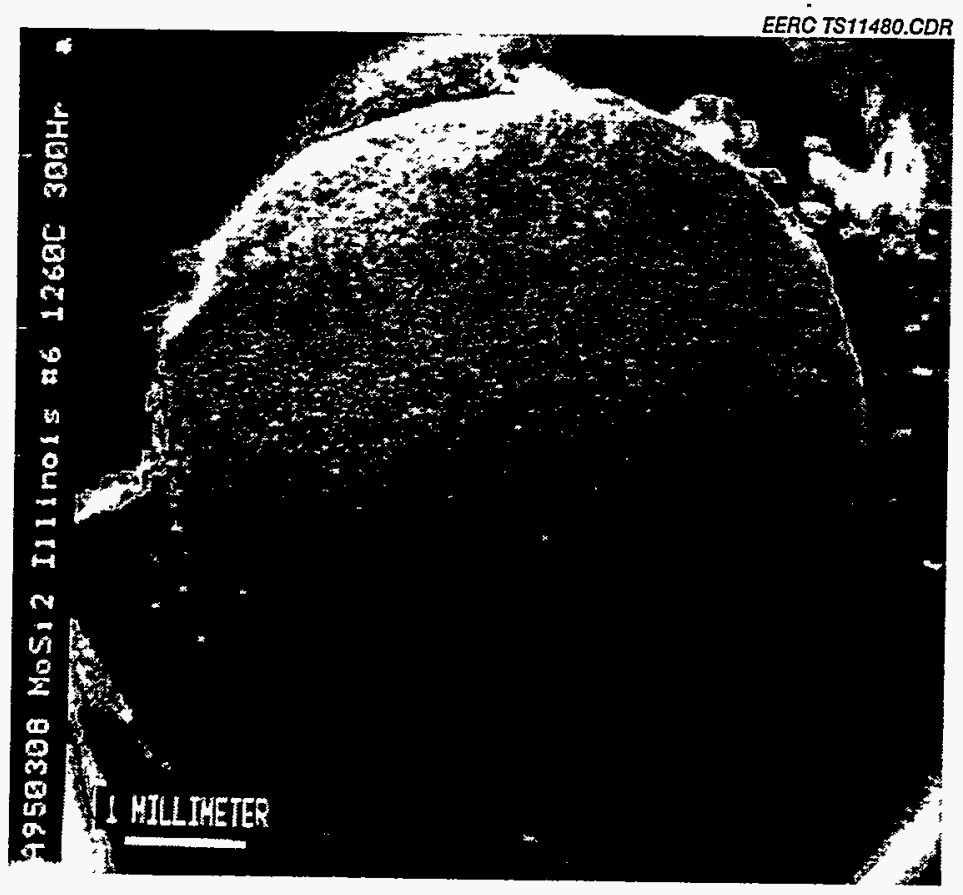

Figure 4. SEM photo showing a cross section through the $\mathrm{MoSi}_{2}$ exposed to the Illinois No. 6 . slag showing little corrosion of the $\mathrm{MoSi}_{2}$ surface. 
of phases, such as magnetite $\left(\mathrm{Fe}_{3} \mathrm{O}_{4}\right)$, during cooling. However, in general, the residual slag contained slightly more silicon and less iron than the original slag. Some areas of the slag also contained several weight percent of Mo.

\subsection{Conclusions}

Pre- and postexposure thicknesses of the materials were measured to determine corrosion depth. Tables 3 and 4 show the results for the 300-hour corrosion experiments performed under the Cooperative Agreement (Coop) and the results from similar 300-hour experiments performed under the Combustion 2000 (C2000) project. Although the exposure time and temperature were identical for the two tests, the $\mathrm{C} 2000$ tests used coal ashes produced by burning pulverized fuel in a droptube furnace, whereas slags from utility cyclone-fired boilers were used for the Coop experiments. Table 5 shows the chemical compositions of the ashes used during the C2000 tests. The Illinois No. 6 ash used in C2000 tests is very similar in composition to the Illinois No. 6 slag from the Baldwin plant (Table 2); however, the Rochelle ash used in the C2000 experiments contains less silica and more calcium oxide than the Rochelle NSP slag. Therefore, the higher silica content in the Rochelle NSP slag may result in a less-corrosive, higher-viscosity slag at the exposure temperature as shown in Figure 5. Viscosity measurements performed under the same atmosphere for the two slags are not available to verify this assumption.

The results for the samples exposed to the Rochelle slags indicate that the $\mathrm{MoSi}_{2}, \mathrm{Si}_{3} \mathrm{~N}_{4}$, and NT230 Si-SiC have the greatest corrosion rates of more than $10 \mathrm{~mm} /$ year $(0.4 \mathrm{in} /$ year) (Table 3$)$. The $\mathrm{SiC}-\mathrm{Al}_{2} \mathrm{O}_{3}$ materials show the slowest corrosion rates of the materials, which may be related to the protective coating of $\mathrm{Al}_{2} \mathrm{O}_{3}$ that develops on the surface of the composite during high-temperature exposure $(12,13)$.

\section{TABLE 3}

Remaining Strengths and Penetration Depths for the Test Samples Exposed at $1260^{\circ} \mathrm{C}$ to Rochelle Slags

\begin{tabular}{|c|c|c|c|c|}
\hline Description & $\begin{array}{c}\text { As-Received } \\
\text { Flexural } \\
\text { Strength, Mpa }\end{array}$ & $\begin{array}{c}\text { Remaining } \\
\text { Strength, } \\
\% \\
\end{array}$ & $\begin{array}{c}\text { Depth of Slag } \\
\text { Penetration, } \\
\mu \mathrm{m}\end{array}$ & $\begin{array}{c}\text { Penetration } \\
\text { Rate, mm/year }\end{array}$ \\
\hline \multicolumn{5}{|l|}{ C2000 Samples: } \\
\hline Standard $\mathrm{SiC}-\mathrm{Al}_{2} \mathrm{O}_{3}$ & 414 & 88 & 75 & 2 \\
\hline $\begin{array}{l}\text { Experimental } \\
\mathrm{SiC}-\mathrm{Al}_{2} \mathrm{O}_{3}\end{array}$ & 414 & NA & 25 & $<1$ \\
\hline NT230 Si-SiC & 386 & 45 & 400 & 12 \\
\hline Hexoloy $\alpha-\mathrm{SiC}$ & 400 & 80 & NA & NA \\
\hline \multicolumn{5}{|l|}{ Coop Samples: } \\
\hline Coors $\beta$-SiC & 371 & NA & 150 & 4 \\
\hline NT154 $\mathrm{Si}_{3} \mathrm{~N}_{4}$ & 490 & NA & 480 & 14 \\
\hline $\mathrm{MoSi}_{2}$ & 450 & NA & 580 & 17 \\
\hline
\end{tabular}

*Not Available. 
TABLE 4

Remaining Strengths and Penetration Depths for the Test Samples

Exposed at $1260^{\circ} \mathrm{C}$ to Illinois No. 6 Slags

\begin{tabular}{|c|c|c|c|c|}
\hline Description & $\begin{array}{c}\text { As-Received } \\
\text { Flexural } \\
\text { Strength, Mpa }\end{array}$ & $\begin{array}{c}\text { Remaining } \\
\text { Strength, } \\
\% \\
\end{array}$ & $\begin{array}{c}\text { Depth of Slag } \\
\text { Penetration, } \\
\mu \mathrm{m}\end{array}$ & $\begin{array}{c}\text { Penetration } \\
\text { Rate, } \mathrm{mm} / \text { year }\end{array}$ \\
\hline \multicolumn{5}{|l|}{ C2000 Samples: } \\
\hline Standard $\mathrm{SiC}-\mathrm{Al}_{2} \mathrm{O}_{3}$ & 414 & 94 & 20 & $<1$ \\
\hline $\begin{array}{l}\text { Experimental } \\
\mathrm{SiC}-\mathrm{Al}_{2} \mathrm{O}_{3}\end{array}$ & 414 & NA & 50 & 1 \\
\hline NT230 & 386 & 53 & 60 & 2 \\
\hline Hexoloy & 400 & 65 & 150 & 4 \\
\hline \multicolumn{5}{|l|}{ Coop Samples: } \\
\hline Coors $\beta-S i C$ & 371 & NA & 75 & 2 \\
\hline NT154 $\mathrm{Si}_{3} \mathrm{~N}_{4}$ & 490 & NA & 160 & 5 \\
\hline $\mathrm{MoSi}_{2}$ & 450 & $\mathrm{NA}$ & 45 & 1 \\
\hline
\end{tabular}

TABLE 5

Compositions of the Rochelle and Illinois No. 6 Ashes Used in the Combustion 2000 Corrosion Tests (normalized weight percents)

\begin{tabular}{lcc}
\hline Sample & $\begin{array}{c}\text { Rochelle Ash } \\
(52765457)\end{array}$ & $\begin{array}{c}\text { Illinois No. 6 Ash } \\
(52765459)\end{array}$ \\
\hline Oxide, wt\% & & \\
$\mathrm{SiO}_{2}$ & 38.7 & 51.2 \\
$\mathrm{Al}_{2} \mathrm{O}_{3}$ & 18.6 & 20.0 \\
$\mathrm{Fe}_{2} \mathrm{O}_{3}$ & 5.8 & 18.4 \\
$\mathrm{TiO}_{2}$ & 1.3 & 0.9 \\
$\mathrm{P}_{2} \mathrm{O}_{5}$ & 1.2 & 0.0 \\
$\mathrm{CaO}$ & 25.2 & 5.5 \\
$\mathrm{MgO}$ & 7.7 & 0.9 \\
$\mathrm{Na}_{2} \mathrm{O}$ & 1.0 & 0.4 \\
$\mathrm{~K}_{2} \mathrm{O}$ & 0.2 & 1.9 \\
$\mathrm{SO}_{3}$ & 0.3 & 0.9 \\
$\mathrm{Closure}$ & & \\
\hline
\end{tabular}




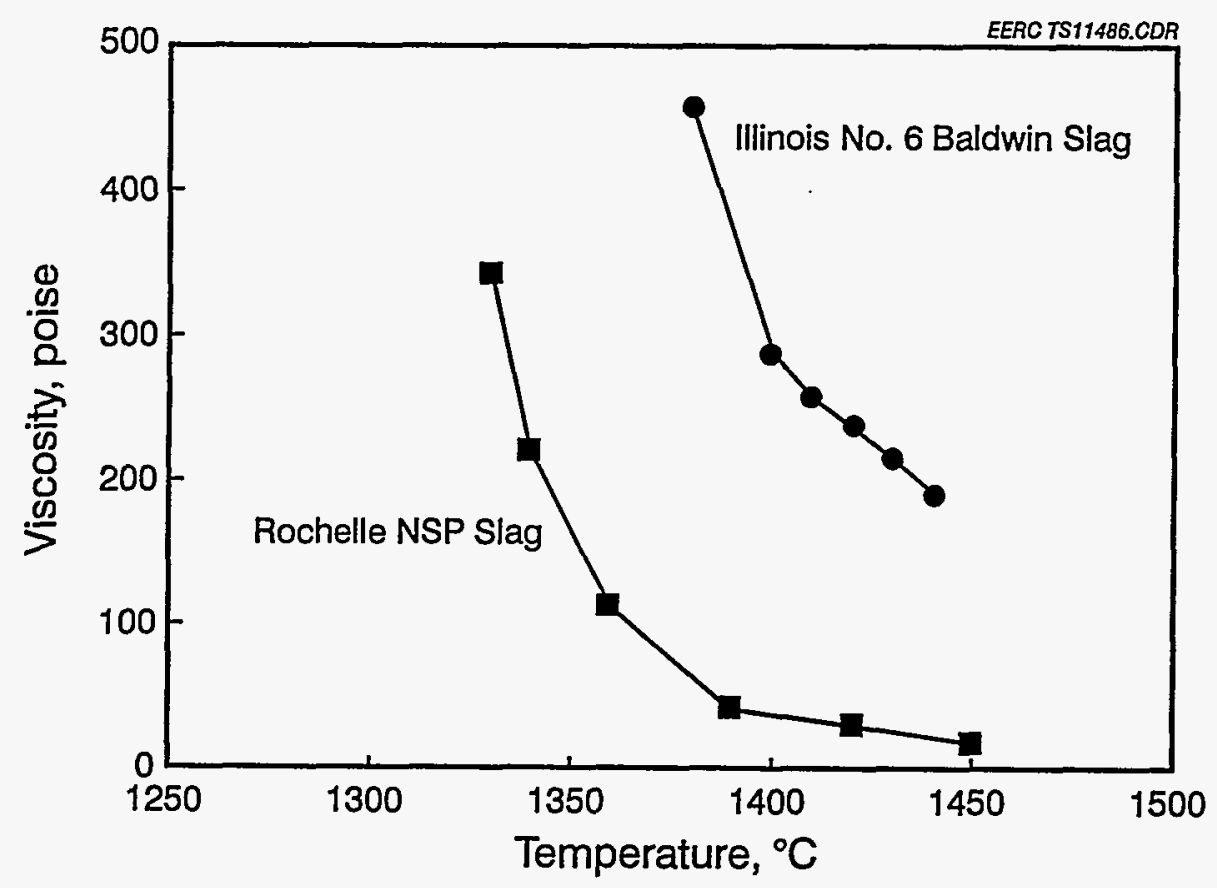

Figure 5. Viscosity vs. temperature in air $+10 \mathrm{wt} \% \mathrm{H}_{2} \mathrm{O}$ for the Illinois No. 6 Baldwin slag and the Rochelle NSP slag.

The greater corrosion of the $\mathrm{Si}-\mathrm{SiC}$ by the Rochelle slag may be related to the residual silicon metal in the material, which has been shown to act as pathways for rapid corrosion $(14,15)$. The poor corrosion resistance of $\mathrm{Si}_{3} \mathrm{~N}_{4}$ has been documented in other static and dynamic corrosion studies performed under similar conditions in Oak Ridge National Laboratory's CRAF facility cofiring an Fe-rich coal with fuel oil (8). $\mathrm{A} \mathrm{Si}_{3} \mathrm{~N}_{4}$ material similar to the NT154 experienced between 20 and $65 \%$ loss in flexural strength after exposure to Fe-rich and Ca-rich coal slags under simulated combustion environments. The lowest loss in strength of $20 \%$ occurred after static laboratory corrosion experiments, while the greatest $(65 \%)$ occurred after dynamic corrosion.

The results for the Illinois No. 6 slags show less variation between sample types (Table 4). Most of the materials have a penetration rate of $<5 \mathrm{~mm} / \mathrm{year}$. In general, all materials performed better after the exposure to the Illinois No. 6 slag than when exposed to the Rochelle slag. The differences in corrosion are probably related to differences in both slag viscosity and chemical reactivity. At $1260^{\circ} \mathrm{C}$, the Rochelle NSP slag has a much lower viscosity than the Illinois No. 6 Baldwin slag (Figure 5), which would allow for more rapid diffusion of corrosive species to, and reaction products from, the ceramic surface.

The results for these two sets of static corrosion experiments indicate that $\mathrm{SiC}-\mathrm{Al}_{2} \mathrm{O}_{3}$ particulate composites, such as the DIMOX Lanxide materials, and sintered SiC, such as Hexoloy $\mathrm{SA}$ and Coors $\beta-\mathrm{SiC}$, may be potential candidates for heat exchanger materials. However, creep may be a problem for the $\mathrm{SiC}-\mathrm{Al}_{2} \mathrm{O}_{3}$ materials at higher temperatures (16). Also, corrosion of 
these materials in a dynamic coal combustion system cannot be ascertained from these static experiments. Therefore, future work should focus on dynamic slag corrosion evaluations.

\subsection{SLAG VISCOSITY MODELING}

\subsection{Introduction}

The study of viscosity began in 1687 with Sir Isaac Newton and, up to now, the record shows little light shed on the molecular basis of viscosity in liquids, particularly in multicomponent aluminosilicates, such as those derived from coal ashes (17). Interest in the viscosity of ash slags today stems from practical applications such as fluxing propensities, corrosion of refractories, sinterability of coal ashes, and high-temperature deformation of silicate binders in $\mathrm{SiC}$ composites used in candle filters. Therefore, the description of melt morphology has become an important factor in understanding the dynamics of mass transport in slags. However, mass transport depends upon the temperature of critical viscosity, $T_{c v}$, at which a slag changes its flowing characteristics from Newtonian to Bingham plastic. In Bingham plastic slags, viscosity increases with progressive phase transformation. The degree of crystallinity of slag is directly proportional to the amount of cooling, though not necessarily linearly below $T_{\mathrm{cv}}(18)$.

A considerable amount of literature now exists regarding the rheology of Bingham plastic solutions such as suspensions (i.e., a combination of liquid plus rigid particles), the viscosity of which depends critically on composition, temperature, and shear rate and on particle abundance, size, size distribution, and shape. For simple systems, the effects of crystals on viscosity can be evaluated. In the case of ash slags, an estimation of slag viscosity in the Bingham plastic region is more complicated, since crystallization usually causes changes in the composition of remaining slags, and the cooling rate may additionally cause a sudden change in the sequence of crystallization. It is suggested here that for the viscosity of ash slag in the Bingham plastic region, it is the interplay of these two factors that primarily controls the slag flow characteristics.

It is the aim of this project to define the phase equilibria in ash slag and apply them in understanding the corrosion of refractories and creep phenomena in binders.

\subsection{Viscosity and Its Practical Application}

In an attempt to explain the viscosity-temperature relationship of silicate glasses, a structural model, based on the variation of the degree of polymerization and, further, on a selective separation of solid material from the melt, has been proposed (17). The degree of polymerization can be described by the proportion of nonbridging oxygens to tetrahedrally coordinated cations ( $\mathrm{NBO} / \mathrm{T}) . \mathrm{NBO}$ is an oxygen atom bound to only one silicon atom, $\mathrm{Si}^{-} \mathrm{O}^{-}$, and to a nontetrahedral cation. For silicate melts, the NBO-to-Si ratio may range from 0 for highly polymerized melts (pure $\left.\mathrm{SiO}_{2}\right)$ to $4\left(\mathrm{SiO}_{4}{ }^{4}\right)$ for highly depolymerized melts (19). Thus, $\mathrm{NBO}$ is a measure of the melt's depolymerization and may provide information on viscosity and diffusivity (from Stokes-Einstein or Eyring equations) mechanisms in slags. The depolymerization process of melts is caused by the alkali and alkaline-earth elements content.

Viscosity sensitivity to the activity of slag constituents based on iron has been explored, in particular, its dependence on oxygen partial pressure. Ferrous iron can depolymerize a slag 
depending on the $\mathrm{CO} / \mathrm{CO}_{2}$ and $\mathrm{H}_{2} / \mathrm{H}_{2} \mathrm{O}$ ratios in the flue gas which, in turn, controls the oxygen partial pressure. High $\mathrm{CO}$ content, formed at the $\mathrm{SiC}$-slag interface during the oxidation of silicon carbide, may further reduce $\mathrm{Fe}^{2+}$ ions to metallic iron and control the formation of iron silicides at the interface. It seems to be important to establish the link between the oxygen partial pressure and the viscosity and phase transformations in ash slags. A further speculation is that the partial pressure of oxygen may control the diffusion of oxygen in a slag and the corrosion rate of SiC. It is expected that the mechanism of $\mathrm{SiC} /$ slag corrosion under combustion conditions will differ from that under gasification conditions. Also, the creep behavior of silicates depends strongly on the partial pressure of oxygen $(20,21)$.

To establish the link between viscosity and phase transformation means to determine and/or predict crystalline phases that may form near the temperature of critical viscosity. Previous attempts to predict the identity of stable phases have been based on free energy minimization techniques (22). They involved calculations of free energies for all possible phases derived from major and minor oxides in multicomponent systems, ignoring constraints imposed by chemical equilibria. The chemical equilibria of the entire nucleation-growth process include growth of nuclei as a result of a large excess of appropriate species in a slag and dissolution of some nuclei into a slag (Ostwald ripening) in a case of a limited content of appropriate species (23). Consequently, nuclei with low free energies, as determined from thermodynamic data, with a limited quantity of appropriate components may either fall toward the ripening stage or participate in the heterogenous nucleation of phases with higher free energies and larger quantities of the appropriate components content (24). To alleviate this problem we have proposed to apply free energy-composition phase diagram rather than temperature-composition phase diagram and free energy of mixing (25). Details of this method will be discussed in the final report. Knowledge of viscosity and phase transformation will allow slagging propensity of ash slags to be defined.

\subsection{On the Crystallinity, Probability of Occurrence, and Rheology of Ash Slags}

The great sensitivity of slag viscosity to the precipitated crystalline-phase content may be a useful qualitative indicator of the mechanism of phase transformation near $T_{c v}$. Figure 6 illustrates viscosity variation with time in Rochelle slag for several temperatures near the temperature of critical viscosity. Viscosity increases because each precipitated solid introduces mechanical interactions and resistance of the slag to flow. The significance of this test is that there is a temperature near $\mathrm{T}_{\mathrm{cv}}$ at which some formed crystalline phases undergo frictional degradation, and the viscosity of the slag slowly decreases.

Generally, viscosity moderately increases with increasing solid-phase content, but the basic mechanics are not well understood.

\subsection{PARTICULATE COAL ASH CORROSION}

Final modifications to the hot-gas reaction furnace (HGRF) have been completed and the 500-hour coal ash corrosion test has been performed. Because of the difficulty in obtaining filter materials, and in joining rings of different materials, only one filter type was tested. Additional tests will be performed on other materials in future research funded by a U.S. Department of Energy-Electric Power Research Institute-industry consortium (EERC Contract Number RP391001) whose inception was aided by early results from this project. 


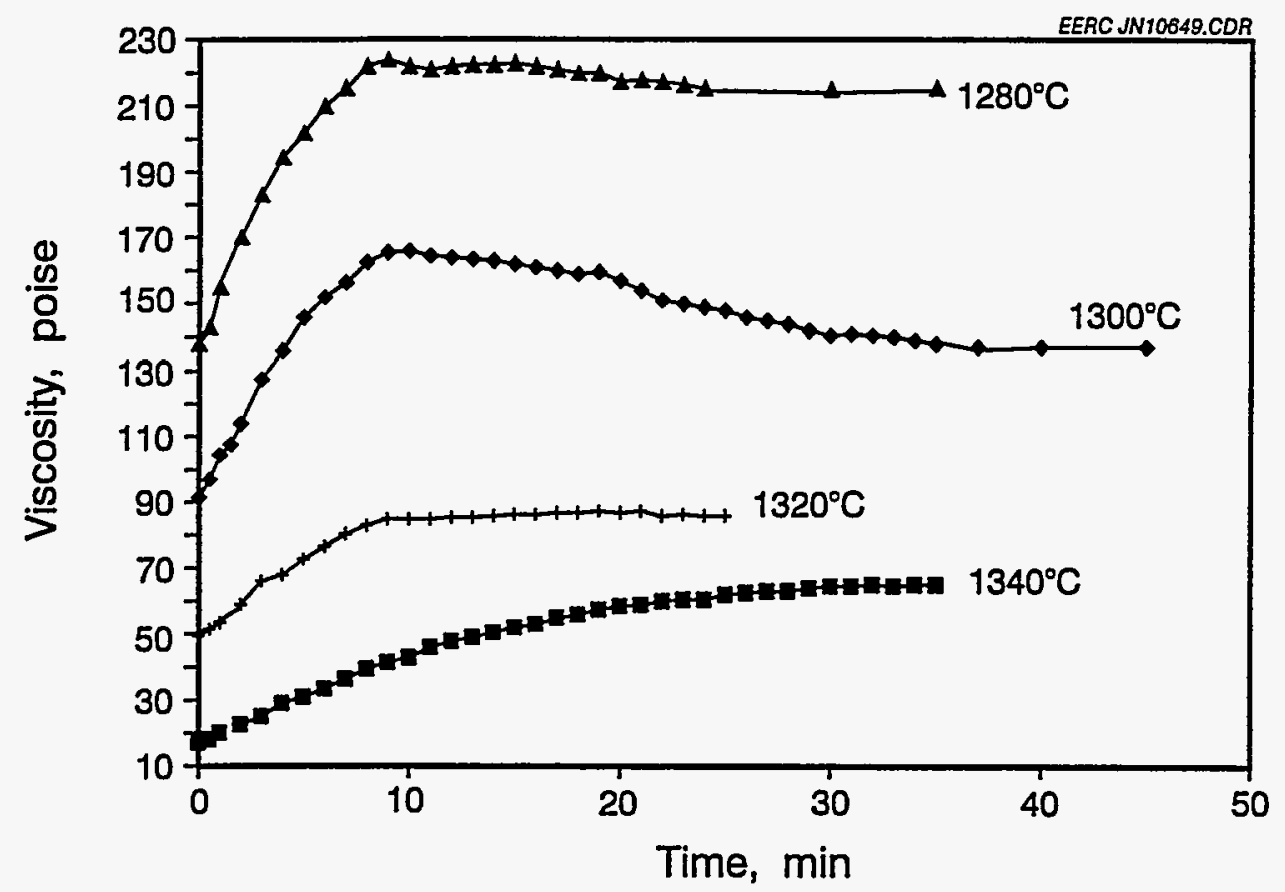

Figure 6. Viscosity of Rochelle ash slag measured in air.

Figures 7 and 8 show a schematic and a photo, respectively, of the completed reactor. Installation of the proposed mullite injector tube and the metering pump proved to be an effective means to inject a metered quantity of alkali into the gas stream. Upon completion of the HGRF, the 500-hour dry ash corrosion test was performed on a 5-inch section of a SiC candle filter provided by Third Millennium. The filter is composed of relatively pure $\mathrm{SiC}$ and made by a patented process that does not use other binder materials.

A photo of the filter assembly in which the filter section was mounted for insertion into the reactor is shown in Figure 9. After the filter was mounted in the filter assembly, the assembly was placed into a small fluidized-bed ash deposition unit. The ash deposition unit creates a fluidized aerosol of ash using compressed air. Connecting a vacuum line onto the exhaust tube of the filter assembly allows a deposit of ash of desired thickness to be pulled onto the filter. For this test, fly ash collected from an electrostatic precipitator at a power plant burning subbituminous coal from the Eagle Butte mine, Powder River Basin, Wyoming, was used. The ash should have been approximately at thermodynamic equilibrium for the test conditions to prevent any secondary reactions with the filter due to chemical instability. An ash cake 1-2 mm thick was grown on the filter in the ash deposition unit. The filter assembly was then inserted into the HGRF with the exhaust tube sealed in the exhaust port and connected to the condenser, as shown in Figure 7. The furnace was then set to ramp to $900^{\circ} \mathrm{C}$ at approximately 4 degrees per minute.

The gas flows were set to produce a simulated combustion gas of $15 \%$ carbon dioxide, $15 \%$ water vapor, $3 \%$ oxygen, and $0.5 \%$ sulfur dioxide in a balance of nitrogen. The gas stream was laden with $10 \mathrm{ppm}$ sodium chloride in solution with the water and injected by the metering pump, 


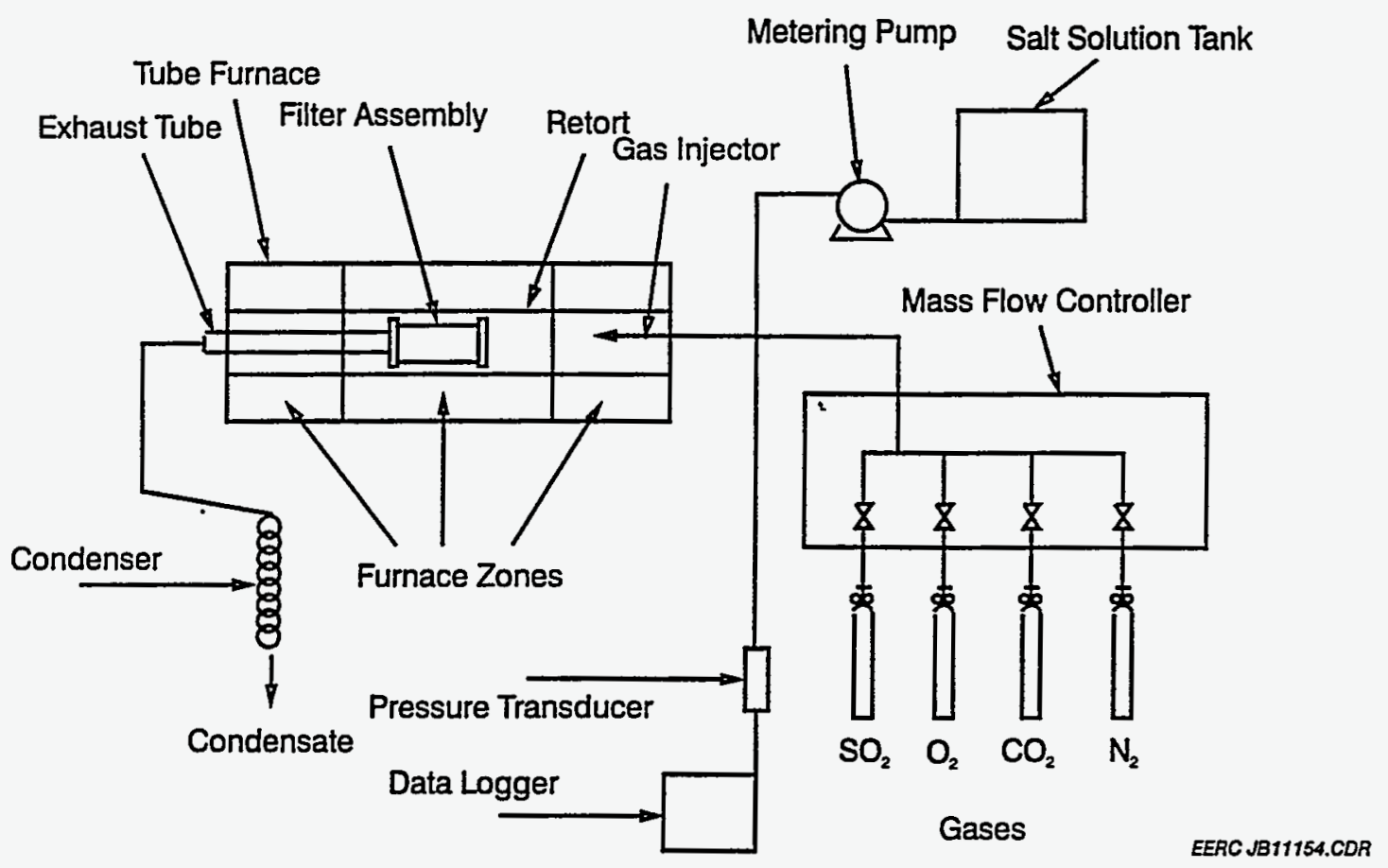

Figure 7. Schematic of hot-gas reactor.

as shown in Figure 7. This gas composition was chosen to simulate the atmosphere in a -pressurized fluidized-bed combustor (PFBC) operating at 10 atmospheres of pressure. Since the HGRF is designed for testing at 1 atmosphere, the concentrations of the alkali and sulfur dioxide were increased to 10 times normal so that the appropriate partial pressures could be obtained.

The backpressure caused by the resistance to the gas flow through the filter and ash cake was monitored continuously. The total gas flow as measured at room temperature was 2.4 liters per minute. This rate of flow caused a constant pressure drop of 0.5 psi for the first 200 hours of the test. The pressure thereafter increased linearly by 1 psi over a period of 120 hours up to a pressure of 3 psi after 500 hours. This behavior is quite different from the experience in an operating filter assembly, for which pressure drop usually increases over a day to $3 \mathrm{psi}$, then levels off. The differences in the pressure drop behavior between the laboratory tests and large-scale filters probably occur because the laboratory filters are not pulse-cleaned.

Figure 10 shows a photograph of a filter before corrosion and the filter section as it appeared after the 500-hour test. There were several large, lengthwise fractures in the filter section after removal from the furnace. Because no significant decrease in pressure drop across the filter was observed during testing, it is most likely that these cracks developed upon cooling the reactor to room temperature, probably as a result of fixturing problems. When the filter sections are bolted into the filter assembly, they are held in considerable compression in order to effect a seal on the 


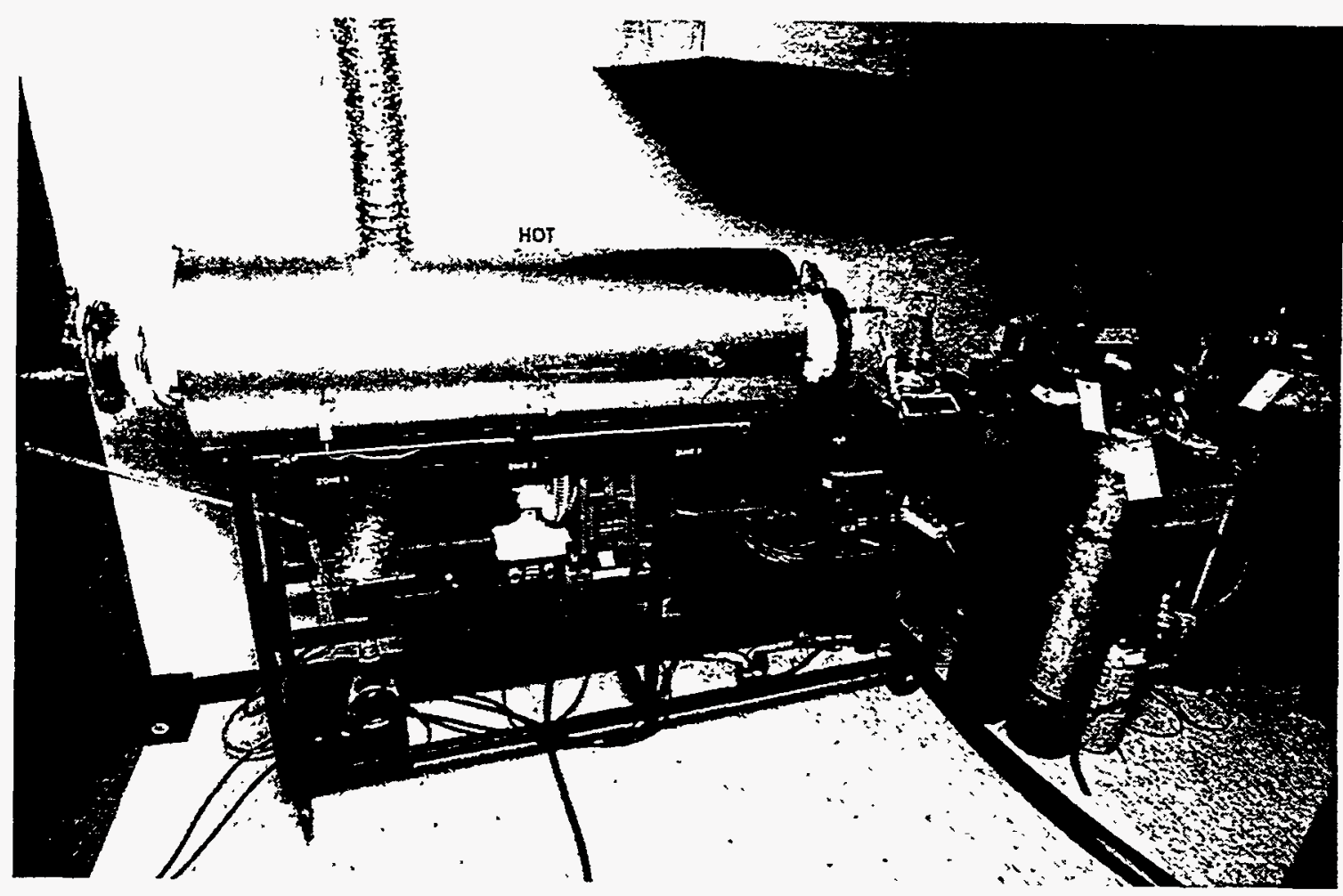

Figure 8. Photograph of completed hot-gas reactor.

ceramic fiber gaskets on each end. As the assembly is heated to the appropriate temperature, the bolts expand approximately 0.064 inches, relieving compressive stress. On cooling, this compression returns, presumably causing fracture of a specimen now weakened because of exposure to the PFBC atmosphere. As can be seen in Figure 10, this recompression also caused spalling of the ash cake near the flanges on the filter assembly. Because of sintering of the ash cake, the deposit became brittle and friable and is most likely responsible for the observed linear increase in pressure drop after 200 hours of exposure. The differences in pressure drop behavior between the laboratory test and a full-scale system indicate that the densification of the residual filter cake and, hence, increase in pressure drop across the cake is accelerated by pulse cleaning in the full-scale system.

SEM analyses of the cakes and cake-filter interface before and after the corrosion tests show no significant interaction between the Third Millenium SiC filter and the ash. Also, the brittle nature of the ash cake made it easy to remove from the filter mechanically, indicating no significant chemical bonding of the ash cake to the filter. However, sintering of the ash was evident as seen in the scanning electron micrographs of the ash cake (Figure 11). Digital analyses of several SEM images show a decrease in porosity of the ash cake from $82 \%$ to $78 \%$, and filter porosity dropped from $50 \%$ to $42 \%$. The large decrease in porosity of the filter can be explained, in part, by the oxidation of the matrix of fine particles of silicon carbide which hold the filter together. The growth of these particles due to oxidation is the only explanation that can be offered at this time for the porosity decrease of the filter material. 


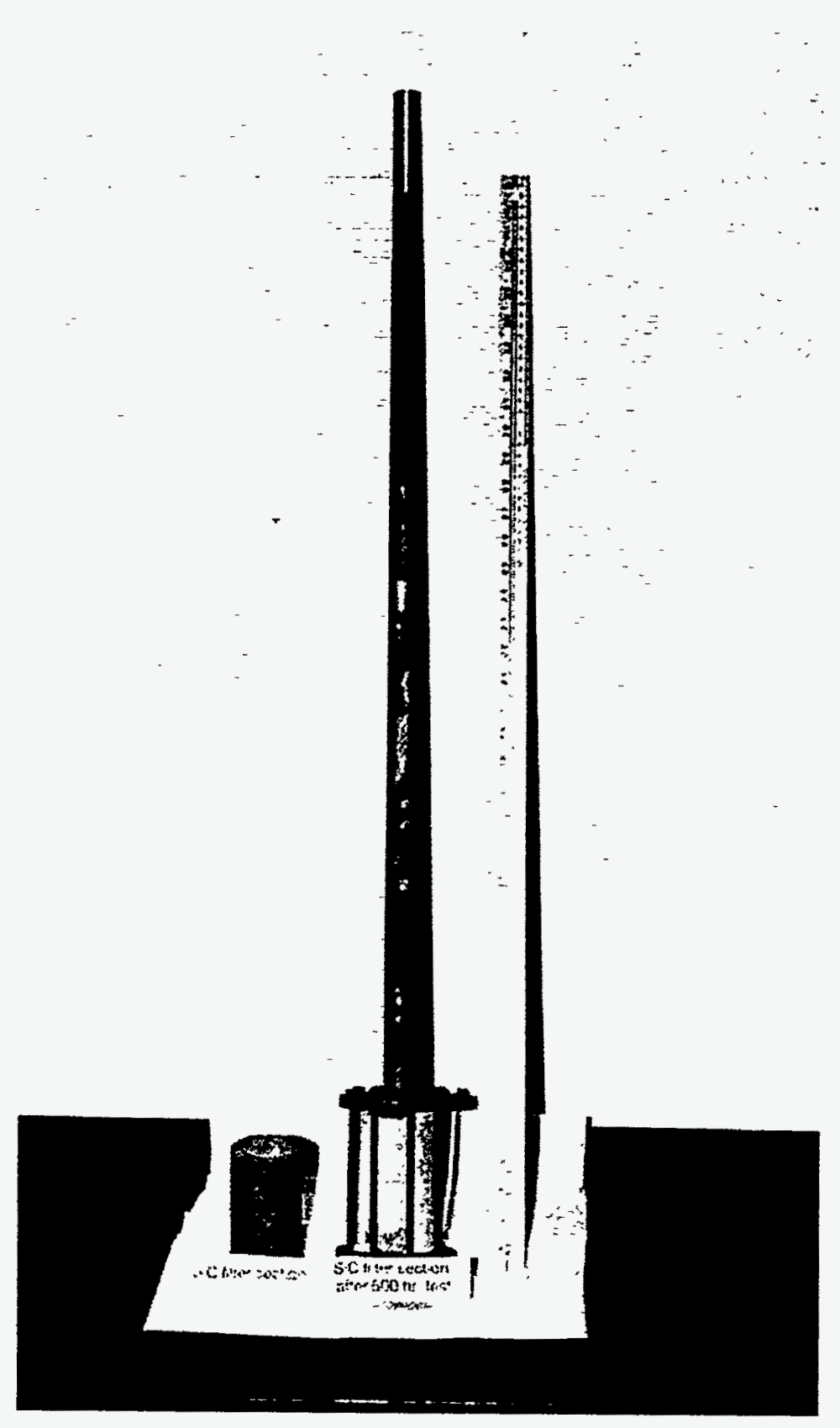

Figure 9. Filter assembly with mounted filter section. 


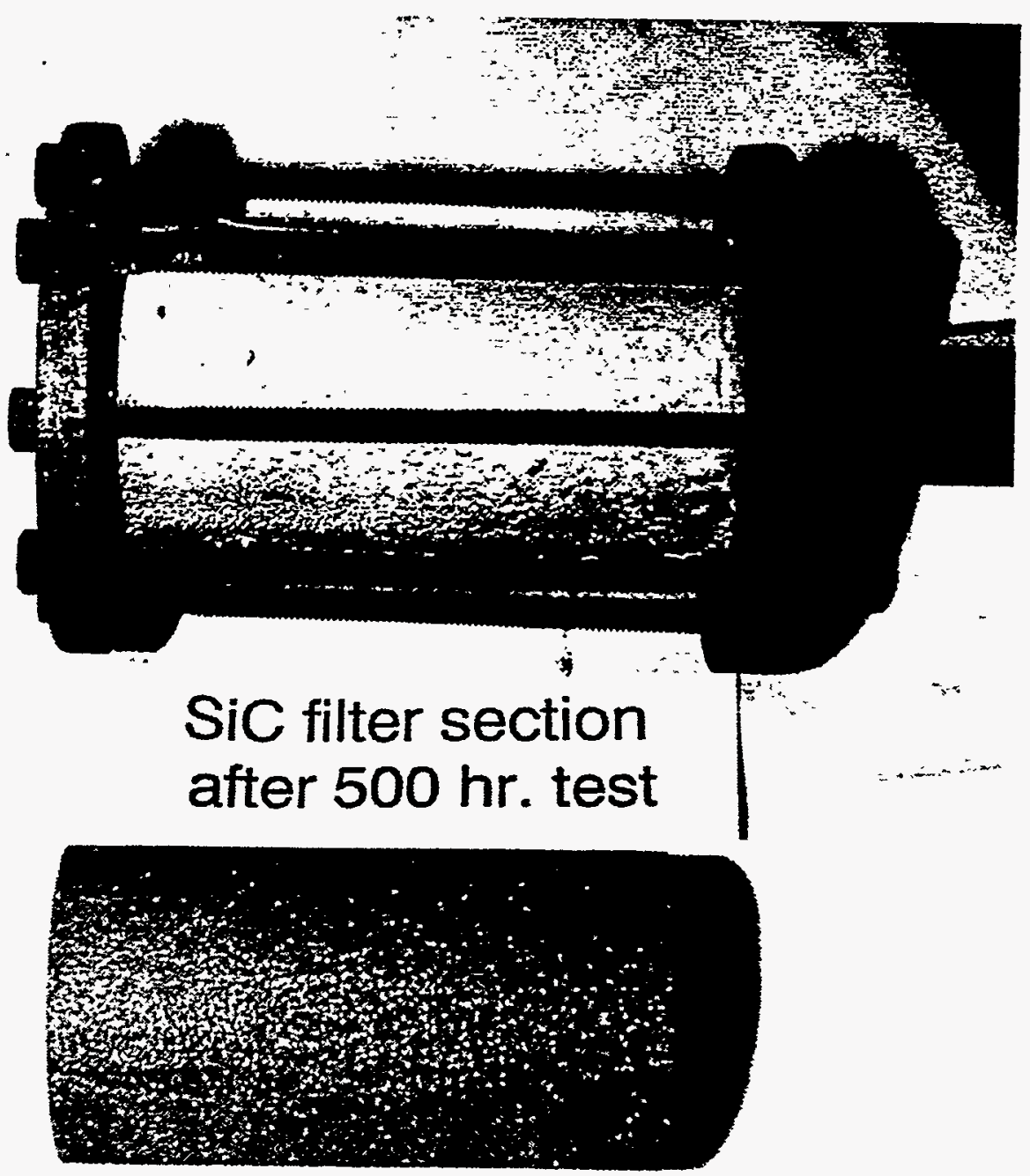

\section{SiC filter section}

Figure 10. Filter sections before and after 500-hour test. 


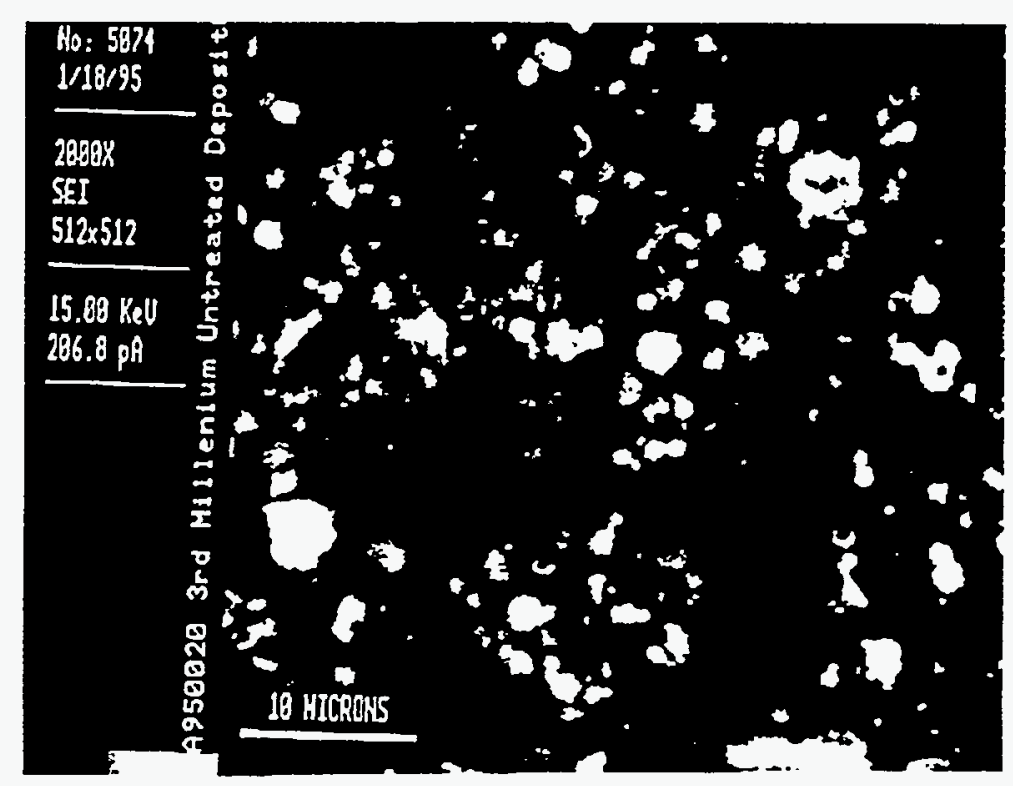

a) before exposure

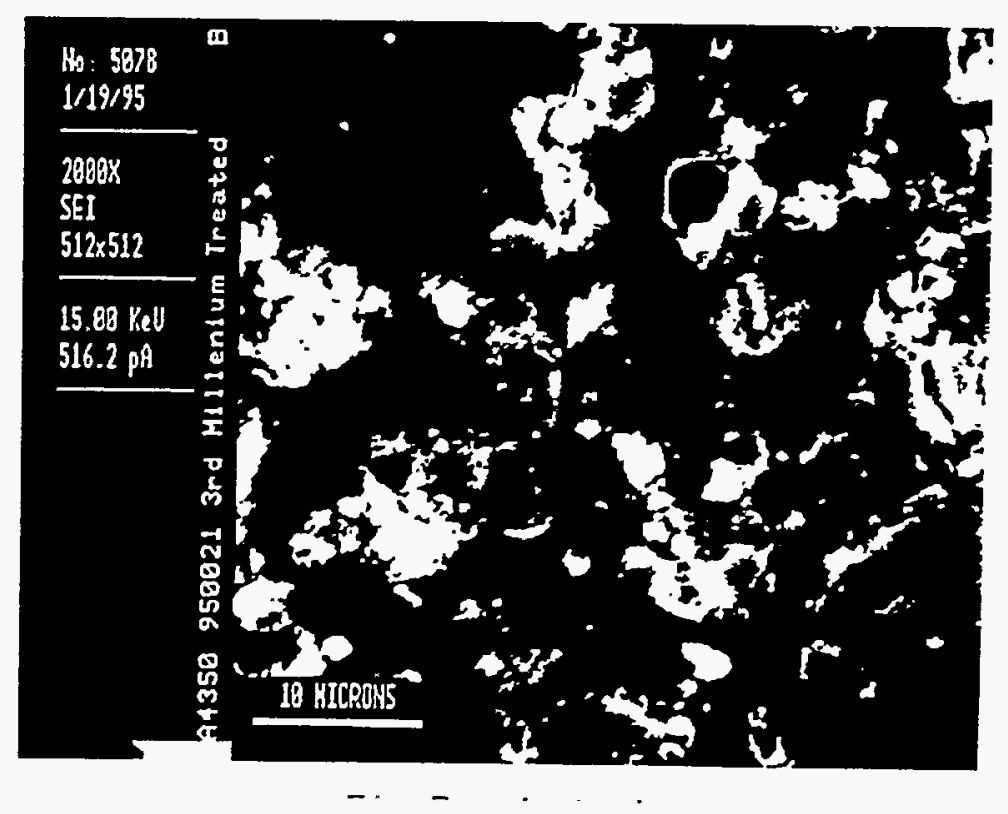

b) after a 500-hour exposure

Figure 11. SEM micrographs of a cross section of the ash cake and filter interface a) before a 500-hour exposure and b) after the 500-hour exposure. 


\subsection{FUTURE WORK}

Under the 1995 Cooperative Agreement, the focus of the materials research will be in the area of joining silicon carbide and silicon nitride structural ceramics.

\subsection{REFERENCES}

1. DeCapitani, C.; Brown, T.H. "The Computation of Chemical Equilibrium in Complex Systems Containing Non-Ideal Solutions," Geochim. Cosmoch. Acta 1987, 51, 2639-2652.

2. Berman, R.G.; Brown, T.H. "Development of Model Multicomponent Melts: Analysis of Synthetic Systems," Reviews in Mineralogy 1987, 17, 405-442.

3. Battezatti, L. "Thermodynamics of Undercooled Melts and Metastable Phase Formation," IST

4. Nowok, J.W. "Viscosity and Phase Transformation in Coal Ash Slags near and below the Temperature of Critical Viscosity," Energy \& Fuel 1994, 8, 1324-1336.

5. Richardson, F.D. Physical Metallurgy; Academic Press: London, 1974; Vol. 1, p 127.

6. Yoder, H.S., Jr. "Melilite Stability and Paragenesis," Fortschr. Miner. 1973, 50, 140-173.

7. Robie, R.A.; Hemingway, B.S.; Fisher, J.R. "Thermodynamic Properties of Minerals and Related Substances at 298.15 and 1 Bar Pressure and at Higher Temperatures," U.S. Geological Survey Bulletin 1452; 1979.

8. Becher, P.F. "Strength Degradation in $\mathrm{SiC}$ and $\mathrm{Si}_{3} \mathrm{~N}_{4}$ Ceramics by Exposure to Coal Slags at High Temperatures," J. Mater. Sci. 1984, 18, 2805-2814.

9. Jacobson, N.S. "Corrosion of Silicon-Based Ceramics in Combustion Environments," $J$. Am. Ceram. Soc. 1993, 76(1), 3-28.

10. Fox, D.S.; Jacobson, N.S. "Molten-Salt Corrosion of Silicon Nitride: I, Sodium Carbonate," J. Am. Ceram. Soc. 1988, 71(2), 128-138.

11. Vitrification Technologies for Treatment of Hazardous and Radioactive Waste, U.S. Environmental Protection Agency Handbook, EPA/625/R-921002, May 1992.

12. Kern, W.A.; Tressler, R.E.; McNallan, M.J. "Durability of $\mathrm{SiC} / \mathrm{Al}_{2} \mathrm{O}_{3}$ Composites in Contact with Sodium Silicate," Center for Advanced Materials Newsletter 1992, 18, 1-17.

13. Strobel, T.M.; Hurley, J.P.; Senior, C.L.; Holowczak, J. "Coal-Slag Corrosion of Silicon Carbide Based Ceramics in a Combustion Environment, "In Proceedings of the Symposium on Silicon-Carbide Based Structural Ceramics, American Ceramic Society PAC RIM Meeting; Honolulu, HI, Nov. 7-10, 1993; pp 327-334. 
14. Fox, D.S.; Jacobson, N.S.; Smialek, J.L. "Hot Corrosion of Silicon Carbide and Silicon Nitride at $1000^{\circ} \mathrm{C}, "$ Ceramic Transactions, 1990, 10, 227-249;

15. Strobel, T.M.; Hurley, J.P.; Breder, K.; Holowczak, J.E. "Coal Slag Corrosion and Strength Degradation of Siliconized Silicon Carbide," In Proceedings of the American Ceramic Society 19th Annual Conference on Composites, Advanced Ceramics, Materials and Structures; Cocoa Beach, FL, Jan. 8-12, 1995; in press.

16. Breder, K:; Tennery, V.J. "Comparison of the Dynamic Fatigue Behavior of Two Monolithic SiCs and an $\mathrm{Al}_{2} \mathrm{O}_{3} / \mathrm{SiC}$ Composite" In Proceedings of the 18th Annual Conference on Composites and Advanced Ceramic Materials, Cocoa Beach, FL Jan. 9-14, 1994;

Ceramics Engineering \& Science Proceedings 1994, July-Aug, 23-31.

17. Nowok, J.W.; Hurley, J.P. "Local Structure of a Lignitic Coal Ash Slag and Its Effect on Viscosity," Energy \& Fuel 1993, 7, 1135-1140.

18. Nowok, J.W. "Viscosity and Phase Transformation in Coal Ash Slags near and below Temperature of Critical Viscosity," Energy \& Fuel, in press.

19. Mysen, B.O. "Structure and Petrology-Important Properties of Silicate Melts Relevant to Natural Magmatic Liquids," In Silicate Melts; Scarfe, C.M., Ed.; Mineralogical Association of Canada, 1986, Vo. 12, pp 180-209.

20. Jaoul, O. "Multicomponent Diffusion and Creep in Olivine," J. Geoph. Res. 1990, 95, $17,631-17,642$.

21. Jaoul, O. "High-Temperature Deformation of Diopside Crystal. 3. Influence of $\mathrm{PO}_{2}$ and $\mathrm{SiO}_{2}$ Precipitation," J. Geoph. Res. 1994, 99, 9423-9439.

22. Harvie, C.E.; Greenberg J.P.; Weare, J.H. Geochim. Cosmoch. Acta 1987, 51, 1045-1057.

23. Bartels, J.; Lembke, U.; Pascova R.; Gutzov, J., J. Non-Crystal. Solids 1991, 136, 181-188.

24. Nowok, J.W. "Analysis of Atomic Diffusion in Liquid Metals at Melting Temperatures in Capillary-Like Media," Acta Metall. Mater., in press.

25. Nowok, J.W. "A Universal Relation between Diffusion, Viscosity, and Surface Tension in Liquid Metals in Capillary-Like Media," Scripta Metall. Mater. 1993, 29, 931-935. 